\title{
Two New Phenolic Glycosides from Rhizomes of Curculigo crassifolia
}

\author{
Ning Li, Ji-Jun Chen, and Jun Zhou \\ State Key Laboratory of Phytochemistry and Plant Resources in West China, Kunming Institute of \\ Botany, Chinese Academy of Sciences, Kunming 650204, Yunnan, P. R. China \\ Reprint requests to Prof. J. Zhou. Fax: +86-871-5223261; E-mail: ln0110@sina.com
}

Z. Naturforsch. 61b, $611-614$ (2006); received December 16, 2005

Curculigo crassifolia (Bak.) Hook. f. (Hypoxidaceae) is a tall perennial herb used as a folk medicine to treat child pneumonia by local people in Yunnan Province. Two new phenolic glycosides named crassifoside C (1) and crassifoside D (2) were isolated from the ethanolic extract of rhizomes of Curculigo crassifolia, and their structures were identified by 2D-NMR spectroscopic techniques and chemical transformations. In addition, seven known compounds (3-9) were isolated and identified by spectroscopic analysis and comparison of their spectral data with those reported previously.

Key words: Curculigo crassifolia, Hypoxidaceae, Phenolic Glycosides

\section{Introduction}

The genus Curculigo (Hypoxidaceae), comprising of about 20 species, are perennial herbs growing in the tropic and subtropic zones of Asia, Africa, South America and Australia, seven of them are found in the south of China [1]. The rhizomes of genus Curculigo are usually considered to be tonic medicines in China, such as C. orchiodes, called as "Xianmao" in Chinese, a traditional anti-ageing medicine has been used since Tang dynasty [2]. Curculigo crassifolia (Bak.) Hook. f. (Hypoxidaceae) is a tall perennial herb with a coat of white hair on the back of leave, distributed in the western and southern of China, north of India and Nepal, its rhizomes were used as a folk medicines to treat child pneumonia by local people, such as Yi, Miao, Hui and Hani in Yunnan Province [1]. Previously, we reported several types of compounds from the rhizomes of plants of genus Curculigo [3-5]. Further investigation on $C$. crassifolia led to the isolation of two new phenolic glycosides $(\mathbf{1}, \mathbf{2})$ and seven known phenolic compounds $(3-9)$. This paper described the isolation and structural elucidation of these compounds.

\section{Results and Discussion}

The $95 \%$ EtOH extract of air-dried and powdered rhizomes of $C$. crassifolia was suspended in $\mathrm{H}_{2} \mathrm{O}$ and then passed through D101 resin column eluting with $\mathrm{H}_{2} \mathrm{O}$ and $\mathrm{EtOH}$ to give EtOH elueted residue $(500 \mathrm{~g})$. Further repeated column chromatography of the EtOH residue on silica gel and Sephadex LH-20 led to the isolation of two new compounds $(\mathbf{1}, \mathbf{2})$ together with seven known compounds identified as isonyasicoside (3) [6-8], pilosidine (4) [8], glucosyringic acid (5) [9], curculigoside I (6) [10], protocatechuic acid (7), 5-O-methylcurculigin (8) [11] and 5-O-methylisocurculigin (9) [11] by comparing data (MS, ${ }^{1} \mathrm{H} \mathrm{NMR}$, ${ }^{13} \mathrm{C} \mathrm{NMR}$ and $[\alpha]_{\mathrm{D}}$ ) with those previously reported or co-TLC with authentic samples (Fig. 1). Structural elucidation of the new compounds $(\mathbf{1}, \mathbf{2})$ was based on the spectroscopic and chemical evidence.

Compound 1 was obtained as white powder. The negative-ion HRFAB MS showed a quasi-molecular ion peak at $m / z 491.1203[\mathrm{M}-\mathrm{H}]^{-}$, in accordance with the molecular formula $\mathrm{C}_{23} \mathrm{H}_{24} \mathrm{O}_{12}-\mathrm{H}$ (calcd. 491.1189). Its IR spectrum indicated the presence of hydroxyl groups $\left(3439 \mathrm{~cm}^{-1}\right)$ and a carbonyl group $\left(1652 \mathrm{~cm}^{-1}\right)$. The NMR data revealed the presence of a 3,4-di-substituted aromatic ring linked to the carbonyl. HMQC and COSY spectra revealed the presence of the fragment of $=\mathrm{CHCH}(\mathrm{O}) \mathrm{CH}(\mathrm{O})-(\mathrm{C}-2$ to $\mathrm{C}-4)$. In the $\mathrm{HMBC}$ spectrum of $\mathbf{1}$, the correlations of $\mathrm{H}-2$ to $\mathrm{C}-9$ and $\mathrm{C}-11, \mathrm{H}-3$ to $\mathrm{C}-1$ and $\mathrm{C}-10$, and $\mathrm{H}-4$ to $\mathrm{C}-5$ and $\mathrm{C}-9$ showed the presence of a benzo $[9,10]$ cyclohexatene linked to the carbonyl. In the HMQC spectrum, two singlet signals at $\delta=7.11(\mathrm{H}-5)$ and $6.52(\mathrm{H}-8)$ had connectivities with carbon atoms at $\delta=114.7(\mathrm{C}-5)$ and $114.4(\mathrm{C}-8)$. The ${ }^{13} \mathrm{C} \mathrm{NMR}$ spectrum indicated the presence of a hexose unit. The anomeric proton signal appeared as a doublet at $\delta=4.47(1 \mathrm{H}, \mathrm{d}, J=7.3 \mathrm{~Hz})$ suggested a $\beta$-configured hexose unit. Glucose was detected by acidic hydrolysis 


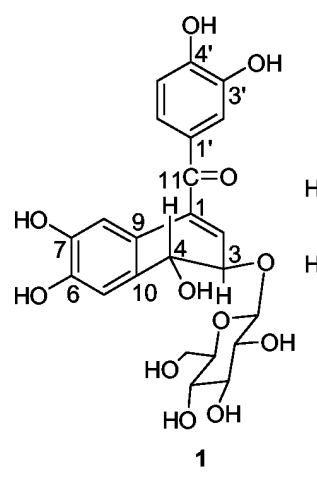

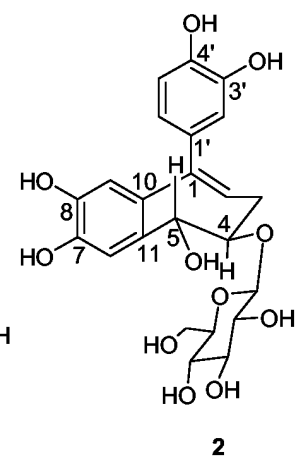<smiles>[R2][C@H](c1ccc(O)c(O)c1)[C@@H](CC#Cc1ccc(O)c(O)c1)[R]([R6])([H])[H]</smiles>

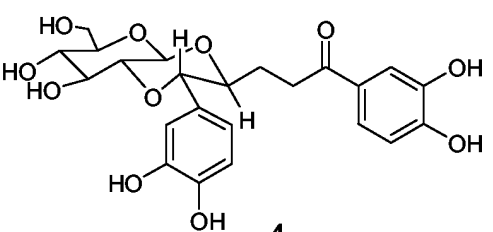<smiles>COc1cccc(OC)c1C(=O)OCc1cc(O)ccc1OC(O)C(O)CO</smiles><smiles>O=C(O)c1ccc(O)c(O)c1</smiles>

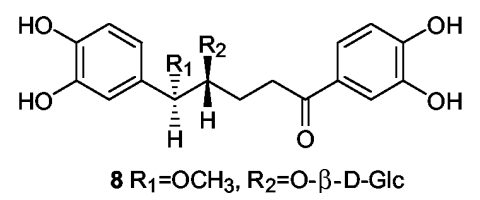<smiles>[R]C([R])[C@H](c1ccc(O)c(O)c1)[C@@H]([R])CCC(=O)c1ccc(O)c(O)c1</smiles>

Fig. 1. Structures of compounds 1 -9 isolated from Curculigo crassifolia. of 1 . In the sugar moiety, the ${ }^{1} \mathrm{H}_{-}{ }^{13} \mathrm{C}$ long-range correlations from the anomeric proton at $\delta=4.47$ to $\mathrm{C}-3$ ( $\delta=81.8$ ) ascertained that the sugar was attached to C-3 at the aglycone. The relative stereochemistry of $\mathbf{1}$ was determined by analysis of its coupling constants of $\mathrm{H}-3$ at $\delta=4.63(\mathrm{dd}, J=10.1,2.5 \mathrm{~Hz}, 1 \mathrm{H})$ and $\mathrm{H}-4$ at $4.87(\mathrm{~d}, J=10.1 \mathrm{~Hz}, 1 \mathrm{H})$, which indicated that $3-O-\beta$-D-glucopyranosyl and 4-hydroxy group should be at $3 \beta, 4 \alpha$-orientation. On acetylation of 1 with acetic anhydride in pyridine, the positive-ion FAB MS analysis of the acetate of 1 showed $m / z 493+9 \times 42$ $\left([\mathrm{M}+1]^{+}+9 \mathrm{Ac}\right)(871)$, which indicated that $\mathbf{1}$ had five free hydroxyl groups located at C-4, C-6, C-7, $\mathrm{C}-3^{\prime}$ and $\mathrm{C}-4^{\prime}$, respectively, the other four acetyl groups were due to the glucose unit. Therefore, the chemical structure of compound $\mathbf{1}$ was deduced as 1-(3,4-dihydroxy-benzoyl)-3 $\beta, 4 \alpha, 6,7$-tetrahydroxy-benzo[9,10]-1-cyclohexatene-3- $O$ - $\beta$-D-pyrano sylglucoside and named crassifoside $\mathrm{C}$.

Compound 2 was obtained as brown powder. The negative-ion HRFAB MS showed a quasi-molecular ion peak at $m / z$ 477.1401 $[\mathrm{M}-\mathrm{H}]^{-}$, in accordance with the molecular formula $\mathrm{C}_{23} \mathrm{H}_{26} \mathrm{O}_{11}-\mathrm{H}$ (calcd. 477.1396). Its IR spectrum indicated the presence of $\mathrm{OH}$ groups $\left(3430 \mathrm{~cm}^{-1}\right)$. The NMR data revealed the presence of a 3,4-di-substituted aromatic ring.
The HMQC and COSY spectra revealed the presence of the fragment of $=\mathrm{CHCH}_{2} \mathrm{CH}(\mathrm{O}) \mathrm{CH}(\mathrm{O})-(\mathrm{C}-2$ to $\mathrm{C}-5)$. In the $\mathrm{HMBC}$ spectrum of 2 , the correlations of $\mathrm{H}-2$ to $\mathrm{C}-1$ and $\mathrm{C}-10, \mathrm{H}-3$ to $\mathrm{C}-1, \mathrm{H}-5$ to $\mathrm{C}-6$, $\mathrm{C}-10$ and $\mathrm{C}-11$, and $\mathrm{H}-9$ to $\mathrm{C}-1$ and $\mathrm{C}-11$ showed the presence of a benzo $[10,11]$ cycloheptene. In the HMQC spectrum, two singlet signals at $\delta=8.21$ (H-6) and 7.29 (H-9) had connectivities with $\mathrm{C}$-atoms at $\delta=113.6(\mathrm{C}-6)$ and $116.9(\mathrm{C}-9)$. Further ${ }^{1} \mathrm{H}_{-}{ }^{13} \mathrm{C}$ long-range correlations of $\mathrm{H}-2^{\prime}$ and $\mathrm{H}-6^{\prime}$ to $\mathrm{C}-1$ showed the 3,4-di-substituted aromatic ring was attached to $\mathrm{C}-1$. The ${ }^{1} \mathrm{H}$ and ${ }^{13} \mathrm{C}$ NMR spectra indicated the presence of a hexose unit. The anomeric proton signal appeared as a doublet at $\delta=5.07$, attributed from the coupling constant of $7.7 \mathrm{~Hz}$ to a $\beta$-configurated anomeric proton. The glucose unit was detected by acidic hydrolysis of $\mathbf{2}$. In the sugar moiety, the ${ }^{1} \mathrm{H}_{-}{ }^{13} \mathrm{C}$ long-range correlations from the anomeric proton at $\delta=5.07$ to $\mathrm{C}-4(\delta=94.8)$ ascertained that the sugar was attached to $\mathrm{C}-4$ at the aglycone. The coupling constant of $8.8 \mathrm{~Hz}$ between $\mathrm{H}-4$ and $\mathrm{H}-5$ indicated that $4-O-\beta$-D-glucopyranosyl and 5-hydroxy group should be at $4 \beta, 5 \alpha$-orientation. On acetylation of $\mathbf{2}$ with acetic anhydride in pyridine, the positive-ion FAB MS analysis of the acetate of $\mathbf{2}$ showed $m / z 479+9 \times 42\left([\mathrm{M}+1]^{+}+9 \mathrm{Ac}\right)(857)$, 
which indicated that $\mathbf{2}$ had five free hydroxyl groups located at C-5, C-7, C-8, C-3' and C-4', respectively and the other four acetyl groups were due to the glucose unit. Thus, 2 was identified as 1-(3,4-dihydroxy phenyl)- $4 \beta, 5 \alpha, 7,8$-tetrahydroxy-benzo[10,11]-1-cycloheptene-4- $O-\beta$-D-pyranosylglucoside and named crassifoside D.

\section{Experimental Section}

General

The optical rotations were run on a JASCO-370 polarimeter. The UV spectra were carried on a UV-2401PC Spectrometer in $\mathrm{MeOH}$. The IR spectra were recorded on a BioRad FTS-35 spectrometer with $\mathrm{KBr}$ pellets. The MS data were performed on an Autospec-3000 spectrometer at a negative ion or positive ion model. 1D and 2D NMR spectra were measured on a Bruker AM-400 or a Bruker DRX-500 spectrometers with TMS as an internal standard. Column chromatography was performed on Sephadex LH-20 (25$100 \mu \mathrm{m}$, Pharmacia Fine Chemical Co. Ltd.) and silica gel (200 - 300 mesh, Qingdao Haiyang Chemical Co.). TLC was carried on silica gel $\mathrm{G}$ precoated plates (Qingdao Haiyang Chemical Co.) and spots were detected by $5 \%$ sulfuric acid reagents followed by heating.

\section{Plant material}

The plant material was collected in Eshan Prefecture, Yunnan Province, China, in October 2002 and identified as Curculigo crassifolia by Prof. Ping-hua YU, Kunming Institute of Botany, Chinese Academy of Science, where a voucher specimen was deposited.

\section{Extraction and isolation}

The air-dried and powered rhizomes of $C$. crassifolia $(10 \mathrm{~kg})$ were extracted with $95 \% \mathrm{EtOH}(3 \times 50 \mathrm{l})$ at r.t., the combined extracts were evaporated in vacuo to afford a residue $(562 \mathrm{~g})$. The residue was suspended in $\mathrm{H}_{2} \mathrm{O}$ and then passed through D101 resin column eluting with $\mathrm{H}_{2} \mathrm{O}$ and $\mathrm{EtOH}$. The EtOH eluent was concentrated in vacuo to give a residue $(500 \mathrm{~g})$, which was fractionated by $\mathrm{CC}$ (silica gel, 3000 g, 200 - 300 mesh; with $\mathrm{CHCl}_{3}-\mathrm{MeOH}, 9$ : 1) to afford 5 fractions (1-5). Fraction $2(13 \mathrm{~g})$ was refractionated on a silica gel column $\left(220 \mathrm{~g}, \mathrm{CHCl}_{3}-\mathrm{MeOH}, 9.5: 0.5,1600 \mathrm{ml}\right)$ to provide 8 fractions (2-1 to 2-8). Fraction 2-5 (448 mg) was purified by repeated Sephadex LH-20 (EtOH) to afford pure $7(82 \mathrm{mg})$. Fraction $3(40 \mathrm{~g})$ was chromatographed on a silica gel column $\left(600 \mathrm{~g}, \mathrm{CHCl}_{3}-\mathrm{MeOH}, 9: 1,2400 \mathrm{ml}\right)$ to provide 9 fractions (3-1 to 3-9). Fraction 3-5 (364 mg) and fraction 3-8 (512 mg) were purified, respectively, by repeated Sephadex LH-20 (EtOH) to afford pure $5(60 \mathrm{mg})$ and 6 $(89 \mathrm{mg})$. Fraction $5(210 \mathrm{~g})$ was refrac- tionated by Sephadex
LH-20 (EtOH-H ${ }_{2} \mathrm{O}, 0: 1-1: 0 ; 2000 \mathrm{ml}$ each eluent) to yield 12 crude fractions (5-1 to 5-12). Fraction 5-7 (4.34 g) was purified by Sephadex LH-20 (EtOH- $\mathrm{H}_{2} \mathrm{O}, 0: 1-1: 0 ; 700 \mathrm{ml}$ each eluent) to yield 6 fractions (5-7-1 to 5-7-6). Fraction 5-7-6 (572 $\mathrm{mg})$ was repeated purified by Sephadex LH-20 (EtOH) to afford a mixture of $\mathbf{8}$ and $\mathbf{9}(112 \mathrm{mg})$. Fraction 5-9 $(48 \mathrm{~g})$ was purified by Sephadex LH-20 $\left(\mathrm{EtOH}-\mathrm{H}_{2} \mathrm{O}, 0: 1-\right.$ $1: 0 ; 1000 \mathrm{ml}$ each eluent) to yield 10 fractions (5-9-1 to 5-9-10). Fr. 5-9-5 (2.96 g) was repeated purified by Sephadex LH-20 (EtOH) to afford pure 3 (700 mg), 4 (34 mg) and 2 (26 mg). Fraction 5-9-9 (140 mg) was purified by Sephadex LH-20 (EtOH) to afford pure $1(60 \mathrm{mg})$.

\section{Acetylation $\mathbf{1}$ and $\mathbf{2}$}

A soln. of each sample $(1 \mathrm{mg})$ in pyridine $(1 \mathrm{ml})$ was treated with $\mathrm{Ac}_{2} \mathrm{O}(1 \mathrm{ml})$ and kept at $60-70{ }^{\circ} \mathrm{C}$ for $3-6 \mathrm{~h}$. The reactants were condensed in vacuo to give a residue, which was purified on a preparative TLC plates with $\mathrm{CHCl}_{3}$ $\mathrm{MeOH}(9: 1)$ to obtain an acetate. The acetate was subjected to FAB MS analysis.

\section{Acidic hydrolysis $\mathbf{1}$ and $\mathbf{2}$}

Each sample ( $3 \mathrm{mg}$ ) was dissolved, respectively, in a mixture of $\mathrm{MeOH}(2.0 \mathrm{ml})$ and $2 \mathrm{~mol} / 1 \mathrm{H}_{2} \mathrm{SO}_{4}(2.0 \mathrm{ml})$ and refluxed on a boiling water bath for $2 \mathrm{~h}$. The hydrolysate was allowed to cool, diluted twofold with distilled $\mathrm{H}_{2} \mathrm{O}$ and partitioned between EtOAc and water. The aq. layer was neutralized with aq. $\mathrm{Ba}(\mathrm{OH})_{2}$ and concentrated in vacuo to give a residue, from which glucose was identified by $\mathrm{PC}$ comparison with authentic sample (n-BuOH-HAc- $\mathrm{H}_{2} \mathrm{O}, 5: 1: 5$, upper layer).

Crassifoside $C(\mathbf{1})$ : White powder. $[\alpha]_{\mathrm{D}}^{23}-50.5^{\circ}$ (c 0.10 , $\mathrm{MeOH}) .-\mathrm{UV}_{\max }(\mathrm{MeOH}): \lambda_{\max }(\lg \varepsilon)=204 \mathrm{~nm}(3.95)$, $283 \mathrm{~nm}(4.45)$. - IR (KBr): $v=3439(\mathrm{OH}), 1652(\mathrm{C}=\mathrm{O})$, 1456, 1296, 1105, $1074 \mathrm{~cm}^{-1} .-{ }^{1} \mathrm{H}$ NMR (400 MHz, $\left.\mathrm{CD}_{3} \mathrm{OD}\right): \delta=6.07(\mathrm{~d}, J=2.5 \mathrm{~Hz}, 1 \mathrm{H}, \mathrm{H}-2), 4.63(\mathrm{dd}$, $J=2.5,10.1 \mathrm{~Hz}, 1 \mathrm{H}, \mathrm{H}-3), 4.87(\mathrm{~d}, J=10.1 \mathrm{~Hz}, 1 \mathrm{H}, \mathrm{H}-4)$, $7.11(\mathrm{~s}, 1 \mathrm{H}, \mathrm{H}-5), 6.52$ (s, 1H, H-8), 7.40 (d, $J=2.0 \mathrm{~Hz}$, $\left.1 \mathrm{H}, \mathrm{H}-2^{\prime}\right), 6.81\left(\mathrm{~d}, J=8.3 \mathrm{~Hz}, 1 \mathrm{H}, \mathrm{H}-5^{\prime}\right), 7.38(\mathrm{dd}, J=2.0$, $\left.8.3 \mathrm{~Hz}, 1 \mathrm{H}, \mathrm{H}-6^{\prime}\right)$, Glc: 4.47 (d, $\left.J=7.3 \mathrm{~Hz}, 1 \mathrm{H}, \mathrm{H}-1^{\prime \prime}\right), 3.35$ (m, 1H, H-2" $), 3.34\left(\mathrm{~m}, 1 \mathrm{H}, \mathrm{H}-3^{\prime \prime}\right), 3.28\left(\mathrm{~m}, 1 \mathrm{H}, \mathrm{H}-4^{\prime \prime}\right)$, $3.40\left(\mathrm{~m}, 1 \mathrm{H}, \mathrm{H}-5^{\prime \prime}\right), 3.62$ (dd, $\left.J=5.3,11.8 \mathrm{~Hz}, 1 \mathrm{H}, \mathrm{H}-6^{\prime \prime} \mathrm{a}\right)$, $3.87\left(\mathrm{dd}, J=1.8,11.8 \mathrm{~Hz}, 1 \mathrm{H}, \mathrm{H}-6{ }^{\prime \prime} \mathrm{b}\right) .-{ }^{13} \mathrm{C}\left\{{ }^{1} \mathrm{H}\right\} \mathrm{NMR}$ $\left(100 \mathrm{MHz}, \mathrm{CD}_{3} \mathrm{OD}\right): \delta=140.0(\mathrm{C}-1), 129.3(\mathrm{C}-2), 81.8$ (C-3), 72.9 (C-4), 114.7 (C-5), 145.4 (C-6), 146.9 (C-7), 114.4 (C-8), 123.8 (C-9), 129.9 (C-10), 197.8 (C-11), 130.3 $\left(\mathrm{C}-1^{\prime}\right), 117.6\left(\mathrm{C}-2^{\prime}\right), 146.5\left(\mathrm{C}-3^{\prime}\right), 153.0\left(\mathrm{C}-4^{\prime}\right), 115.9\left(\mathrm{C}-5^{\prime}\right)$, $125.6\left(\mathrm{C}-6^{\prime}\right)$, Glc: $103.5\left(\mathrm{C}-1^{\prime \prime}\right), 71.6\left(\mathrm{C}-2^{\prime \prime}\right), 78.1\left(\mathrm{C}-3^{\prime \prime}\right)$, $74.9\left(\mathrm{C}-4^{\prime \prime}\right), 77.9\left(\mathrm{C}-5^{\prime \prime}\right), 62.7\left(\mathrm{C}-6^{\prime \prime}\right)$. - FAB MS $m / z: 491$ [M-H] $]^{-},-$HRFAB MS $m / z: 491.1203[\mathrm{M}-\mathrm{H}]^{-}$, calcd. for $\left[\mathrm{C}_{23} \mathrm{H}_{23} \mathrm{O}_{12}\right]^{-}: 491.1189$. 
Crassifoside D (2): Brown powder. $[\alpha]_{\mathrm{D}}^{29}-145.8^{\circ}$ (c 0.27, $\mathrm{MeOH}) .-\mathrm{UV}_{\max }(\mathrm{MeOH}): \lambda_{\max }(\lg \varepsilon)=208 \mathrm{~nm}(4.49)$, $363 \mathrm{~nm}$ (2.58), $375 \mathrm{~nm}$ (2.39). - IR (KBr): $v=3430(\mathrm{OH})$, 1543, 1510, 1074, $1021 \mathrm{~cm}^{-1}$. - ${ }^{1} \mathrm{H}$ NMR (400 MHz, $\left.\mathrm{C}_{5} \mathrm{D}_{5} \mathrm{~N}\right): \delta=6.40(\mathrm{t}, J=6.9 \mathrm{~Hz}, 1 \mathrm{H}, \mathrm{H}-2), 2.27(\mathrm{~m}, 1 \mathrm{H}$, H-3a), 2.72 (m, 1H, H-3b), 4.63 (m, 1H, H-4), 5.24 (d, $J=8.8 \mathrm{~Hz}, 1 \mathrm{H}, \mathrm{H}-5), 8.21$ (s, 1H, H-6), 7.29 (s, 1H, H-9), $7.35\left(\mathrm{~d}, J=1.9 \mathrm{~Hz}, 1 \mathrm{H}, \mathrm{H}-2^{\prime}\right), 7.20(\mathrm{~d}, J=8.2 \mathrm{~Hz}, 1 \mathrm{H}$, H-5 $\left.5^{\prime}\right), 6.91\left(\mathrm{dd}, J=1.9,8.2 \mathrm{~Hz}, 1 \mathrm{H}, \mathrm{H}-6^{\prime}\right)$, Glc: 5.07 (d, $\left.J=7.7 \mathrm{~Hz}, 1 \mathrm{H}, \mathrm{H}-1^{\prime \prime}\right), 4.21\left(\mathrm{~m}, 1 \mathrm{H}, \mathrm{H}-2^{\prime \prime}\right), 4.04(\mathrm{~m}, 1 \mathrm{H}$, $\left.\mathrm{H}-3^{\prime \prime}\right), 4.06\left(\mathrm{~m}, 1 \mathrm{H}, \mathrm{H}-4^{\prime \prime}\right), 4.26\left(\mathrm{~m}, 1 \mathrm{H}, \mathrm{H}-5^{\prime \prime}\right), 4.34$ (dd, $\left.J=5.5,11.0 \mathrm{~Hz}, 1 \mathrm{H}, \mathrm{H}-6^{\prime \prime} \mathrm{a}\right), 4.56(\mathrm{dd}, J=1.6,11.0 \mathrm{~Hz}, 1 \mathrm{H}$, $\mathrm{H}-6{ }^{\prime \prime}$ b) $-{ }^{13} \mathrm{C}\left\{{ }^{1} \mathrm{H}\right\}$ NMR (100 MHz, $\left.\mathrm{C}_{5} \mathrm{D}_{5} \mathrm{~N}\right): \delta=143.8$ (C-1), 123.0 (C-2), 31.6 (C-3), 94.8 (C-4), 74.6 (C-5), 113.6 (C-6), 145.6 (C-7), 146.7 (C-8), 116.9 (C-9), 129.5 (C-10),
$134.4(\mathrm{C}-11), 134.4\left(\mathrm{C}-1^{\prime}\right), 117.7\left(\mathrm{C}-2^{\prime}\right), 146.9\left(\mathrm{C}-3^{\prime}\right), 147.0$ (C-4'), $116.4\left(\mathrm{C}-5^{\prime}\right), 120.2\left(\mathrm{C}-6^{\prime}\right)$, Glc: $103.6\left(\mathrm{C}-1^{\prime \prime}\right), 71.9$ $\left(\mathrm{C}-2^{\prime \prime}\right), 78.7\left(\mathrm{C}-3^{\prime \prime}\right), 75.1\left(\mathrm{C}-4^{\prime \prime}\right), 78.5\left(\mathrm{C}-5^{\prime \prime}\right), 62.7\left(\mathrm{C}-6^{\prime \prime}\right)$. FAB MS $m / z: 477[\mathrm{M}-\mathrm{H}]^{-},-$HR FAB MS $m / z: 477.1401$ $[\mathrm{M}-\mathrm{H}]^{-}$, calcd. for $\left[\mathrm{C}_{23} \mathrm{H}_{25} \mathrm{O}_{11}\right]^{-}: 477.1396$.

\section{Acknowledgements}

This project and previous reports relevant to Curculigo spp. from our group are financially supported by the BioTechnique bureau, Chinese Academy of Sciences (KGCX2SW-213-03) and the authors are grateful to the staffs of the analytical group at the State Key Laboratory of Phytochemistry and Plant Resources in West China, Kunming Institute of Botany, Chinese Academy of Sciences for their measuring spectral data.
[1] Institutum Botanicum Kunmingense, Academiae Sinicae, Flora Yunnanica, Vol. 6, p. 816-820. Science Press, Beijing (1995).

[2] State Pharmacopeia Commission of P. R. China, Pharmacopoeia of the P. R. China, Vol. I, p. 75-76. People's Health Publishing House and Chemical Industry Publishing House, Beijing (2000).

[3] N. Li, A. Q. Jia, Y. Q. Liu, J. Zhou, Acta Botanica Yunnanica 25, 241 (2003).

[4] N. Li, N. H. Tan, J. Zhou, J. Asian Nat. Prod. Res. 6, 7 (2004).

[5] N. Li, J. J Chen, J. Zhou, Helv. Chim. Acta 87, 845 (2004).
[6] W. L. Chang, C. H. Chen, S.S. Lee, J. Nat. Prod. 62, 734 (1999).

[7] C. Galeffi, G. Multari, J. G. Msonthi, M. Nicoletti, G. B. Marini-Bettolo, Tetrahedron 43, 3519 (1987).

[8] G. Palazzino, C. Galeffi, E. Federici, F. Delle Monache, M.F. Cometa, M. Palmery, Phytochemistry 55, 411 (2000).

[9] G. H. Bao, L. Q. Wang, K. F. Cheng, Y. H. Feng, X. Y. Li, G. W. Qin, Planta Med. 69, 434 (2003).

[10] C. H. Chen, W. Ni, W. L. Mei, Acta Botanica Yunnanica 21, 521 (1999).

[11] K. Chifundera, G. Palazzino, I. Messana, L. Ping, C. Galeffi, G. Cannarsa, Phytochemistry 35, 1343 (1994). 